\title{
Correlation Between Stress Scale and Serum Substance P Level in Acne Vulgaris
}

This article was published in the following Dove Press journal:

International Journal of General Medicine

\author{
Nelva Karmila Jusuf (D) \\ Imam Budi Putra $\mathbb{D}$ \\ Angie Regina Sutrisno (D) \\ Department of Dermatology and \\ Venereology, Faculty of Medicine, \\ Universitas Sumatera Utara, Medan, \\ Indonesia
}

\begin{abstract}
Introduction: Acne vulgaris is a chronic inflammatory disease of pilosebaceous follicles with polymorphic lesions, consisting of comedones, papules, pustules and nodules with varying degrees of severity. Stress is one of the triggers of acne vulgaris. Peripheral nerves release substance $\mathrm{P}$ in response to stress. Substance $\mathrm{P}$ causes proliferation and differentiation of sebaceous glands and increases lipid synthesis in sebocytes.

Purpose: To determine the correlation between stress scale and serum substance P level in acne vulgaris.
\end{abstract}

Patients and Methods: This study was an observational analytic study with a crosssectional design involving 30 patients with acne vulgaris and 30 controls. History taking, dermatological examination and the Holmes-Rahe stress scale questionnaire were performed with each patient to evaluate stress scale, followed by taking blood samples to assess substance P serum levels using the ELISA test. The collected data were analyzed using the Spearman correlation test.

Results: In both groups, the majority of subjects were 23-27 years old (36.7\%) and most of them were female $(76.7 \%)$. The majority in the acne vulgaris group had low scores on the stress scale, represented by 17 patients $(56.7 \%)$. The main cause of stress in the acne vulgaris group was a major change in sleeping habits (66.7\%). In the acne vulgaris group, the highest mean value of serum substance P level in high stress scale group was $168.2 \mathrm{pg} / \mathrm{mL}$. There was a positive correlation between stress scale and serum substance $\mathrm{P}$ level in acne vulgaris with moderate strength and this was statistically significant $(r=0.446 ; p=0.014)$. Meanwhile, stress scale and serum substance $\mathrm{P}$ level in controls were not correlated and this was not statistically significant $(\mathrm{r}=-0.090 ; \mathrm{p}=0.636)$.

Conclusion: There was a correlation between stress scale and serum substance $\mathrm{P}$ level in acne vulgaris.

Keywords: acne vulgaris, stress scale, substance $\mathrm{P}$

\section{Introduction}

Acne vulgaris is a chronic inflammatory disease of pilosebaceous follicles with polymorphic form such as comedones, papules, pustules and nodules with various degrees of severity. ${ }^{1,2}$ Acne vulgaris is most commonly found on the face, neck, chest and back. ${ }^{3,4}$

About $85 \%$ of acne vulgaris is found at the age of $12-25$ years, with the main peak occurring at the age of 16-19 years in men or 14-17 years in women. ${ }^{1,5}$ In Indonesia, acne vulgaris is a commonly found disease in nearly $80-100 \%$ of the population. ${ }^{6}$ The proportion of acne vulgaris patients in Universitas Sumatera Utara Hospital was 42 from a total of 2138 visits from January to December $2018 .^{7}$
Correspondence: Nelva Karmila Jusuf Faculty of Medicine, Universitas Sumatera Utara, Jl Dr. Mansur No. 5, Kampus USU, Padang Bulan, Medan, 20155, Indonesia Email edelweiss.flowers13@gmail.com
International Journal of General Medicine 202I:|4 68|-686 
Stress is one of the triggers of acne vulgaris. Stress occurs because of a stimulus inducing reactions in the brain. There is strong evidence that the correlation between stress and acne vulgaris is centered on the hypothalamic-pituitary-adrenal (HPA) axis which affects sebaceous gland function. The sebaceous glands in the skin have corticotropin releasing hormone (CRH) receptors, so an increase of CRH in stress can stimulate the formation of sebum which will clog the pilosebaceous gland ducts. Yosipotich et al in their research stated that the sebaceous follicular glands in addition to expressing $\mathrm{CRH}$ receptors can also contain neuropeptide receptor $\alpha$ melanocyte-stimulating hormone ( $\alpha$-MSH), $\beta$-endorphin, vasoactive intestinal polypeptide (VIP), neuropeptide $\mathrm{Y}$ and calcitonin gene-related peptide (CGRP). The binding of neuropeptides with their receptors causes an increase in the production of proinflammatory cytokines, which results in proliferation, differentiation and lipogenesis of pilosebaceous glands. ${ }^{3,8-10}$

There is still limited study that evaluates level of substance $\mathrm{P}$ in patients with acne vulgaris. The objective of the study is to discover the correlation between stress scale and serum substance $P$ level in acne vulgaris and to compare it with a control group.

\section{Patients and Methods}

This is an observational analytic study with a crosssectional design involving 30 patients with acne vulgaris in the Dermatology and Venereology outpatient clinic at Universitas Sumatera Utara Hospital in Medan, Indonesia and 30 controls from June 2020 until August 2020. The control group was taken from healthy people. Blood samples were examined at the Laboratorium Terpadu, Faculty of Medicine, Universitas Sumatra Utara. Inclusion criteria in both groups included being older than 18 years and signing informed consent. Exclusion criteria in both groups included pregnancy, breastfeeding, other stressrelated skin diseases such as psoriasis and atopic dermatitis, systemic diseases, psychiatric diseases and using any systemic drug.

Patients' demographic data consisting of age and gender were taken from medical records. The researcher recorded patient demographic data including age, gender, phone number and address, then examined the patients. The Holmes-Rahe stress scale questionnaire consisting of 43 questions was distributed to each patient to evaluate stress scale, followed by blood sample taking to assess serum substance P level with the ELISA test (Substance
P Kit from the R\&D System Catalogs). The social readjustment rating scale questionnaire instrument by Thomas Holmes and Richard Rahe has a good level of validity and reliability with a Cronbach's alpha value of 0.988 in the population. Each statement on the questionnaire has a different value: low stress scale if the total is $11-149$, medium stress scale 150-299 and high stress scale 300-600. The diagnosis of acne vulgaris was made based on history taking and dermatological test. The collected data were analyzed using Spearman correlation.

We declare that the procedures were followed according to the regulations established by the Clinical Research and Ethics Committee and the Declaration of Helsinki of the World Medical Association. This study was conducted after receiving approval from the Ethics Commission in the Faculty of Medicine of Universitas Sumatera Utara/ Adam Malik Hospital, number 226/TGL/KEPK FK USURSUP HAM/2020.

\section{Results}

Demographic characteristics of research subjects are described in Table 1. Samples were collected from 30 patients with acne vulgaris and 30 controls. In each group, most subjects were in the age group of 23-27 years, represented by 11 subjects (36.7\%), followed by the age group of 28-32 years, represented by 9 subjects $(30 \%)$. The mean age in both groups was 29.28 years. Based on gender, there were more female subjects, represented by 23 subjects (76.7\%), than male subjects, represented by 7 subjects $(23.3 \%)$ in both the acne vulgaris and control groups.

Table I Demographic Characteristics of Research Subjects

\begin{tabular}{|l|c|c|c|c|}
\hline \multirow{2}{*}{ Characteristics } & \multicolumn{2}{|c|}{ Acne Vulgaris Group } & \multicolumn{2}{c|}{ Control Group } \\
\cline { 2 - 5 } & $\mathbf{n}$ & $\%$ & $\mathbf{n}$ & $\%$ \\
\hline Age & & & & \\
I8-22 years old & 4 & 13.3 & 4 & 13.3 \\
23-27 years old & $\mathrm{II}$ & 36.7 & $\mathrm{II}$ & 36.7 \\
28-32 years old & 9 & 30 & 9 & 30 \\
33-37 years old & 3 & 10 & 3 & 10 \\
$\geq 38$ years old & 3 & 10 & 3 & 10 \\
\hline Gender & & & & \\
Male & 7 & 23,3 & 7 & 23.3 \\
Female & 23 & 76.7 & 23 & 76.7 \\
\hline Total & 30 & 100 & 30 & 100 \\
\hline
\end{tabular}


Table 2 Distribution of Subjects Based on Stress Scale

\begin{tabular}{|l|c|c|c|c|}
\hline \multirow{2}{*}{ Stress Scale } & \multicolumn{2}{|c|}{ Acne Vulgaris Group } & \multicolumn{2}{c|}{ Control Group } \\
\cline { 2 - 5 } & $\mathbf{n}$ & $\%$ & $\mathbf{n}$ & $\%$ \\
\hline Low & 17 & 56.7 & 21 & 70 \\
Moderate & 12 & 40 & 7 & 23.3 \\
High & $\mathrm{I}$ & 3.3 & 2 & 6.7 \\
\hline Total & 30 & 100 & 30 & 100 \\
\hline
\end{tabular}

Subject distribution based on stress scale is illustrated in Table 2. This study found that the majority of patients in the acne vulgaris group had a low stress scale, represented by $56.7 \%$ of subjects, followed by $40 \%$ of subjects with a moderate stress scale and $3.3 \%$ of subjects with a high stress scale. Meanwhile, the majority of patients in the control group had a low stress scale, represented by 21 patients $(70 \%)$, followed by 7 patients with a moderate stress scale $(23.3 \%)$ and 2 patients with a high stress scale $(6.7 \%)$.

Subject distribution of the 10 most chosen life events based on the Holmes-Rahe stress scale questionnaire in the acne vulgaris group in this study discovered that stress was mostly caused by major changes in sleeping habits (66.7\%), vacation $(53.3 \%)$, personal habits $(50 \%)$ and eating habits (50\%), which are presented in Table 3.

Distribution of serum substance P level based on stress scale is demonstrated in Table 4. The acne vulgaris group

Table 3 Distribution of the 10 Most Chosen Life Events Based on the Holmes-Rahe Stress Scale Questionnaire in the Acne Vulgaris Group

\begin{tabular}{|l|c|c|}
\hline \multirow{2}{*}{ Holmes-Rahe Stress Scale } & \multicolumn{2}{|c|}{ Frequency (n = 30) } \\
\cline { 2 - 3 } & $\begin{array}{c}\text { Number } \\
\text { (n) }\end{array}$ & $\begin{array}{c}\text { Percentage } \\
\text { (\%) }\end{array}$ \\
\hline Major change in sleeping habits & 20 & 66.7 \\
Vacation & 16 & 53.3 \\
Revision of personal habits & 15 & 50 \\
Major change in eating habits & 15 & 50 \\
Major change in usual type and/or & 14 & 46.7 \\
amount of recreation & 13 & 43.3 \\
Major change in financial state & II & 36.7 \\
Major change in number of family get- & & \\
togethers & 9 & 30 \\
Major change in social activities & 8 & 26.7 \\
Major changes in working hours or & & \\
conditions & 7 & 23.3 \\
Beginning or ceasing formal schooling & & \\
\hline
\end{tabular}

Table 4 Distribution of Serum Substance $P$ Level Based on Stress Scale

\begin{tabular}{|l|c|c|c|c|}
\hline \multirow{3}{*}{ Stress Scale } & \multicolumn{3}{|c|}{ Serum Substance P Level (pg/mL) } \\
\cline { 2 - 5 } & \multicolumn{2}{|c|}{ Acne Vulgaris Group } & \multicolumn{2}{c|}{ Control Group } \\
\cline { 2 - 5 } & n & Mean \pm SD & n & Mean \pm SD \\
\hline Low & 17 & $50 \pm 23.1$ & 21 & $37.7 \pm 15.4$ \\
Moderate & 12 & $71.6 \pm 25.5$ & 7 & $52.3 \pm 18$ \\
High & 1 & 168.2 & 2 & $26.3 \pm 14$ \\
\hline
\end{tabular}

showed that the highest mean value of serum substance P level in the high stress scale was $168.2 \mathrm{pg} / \mathrm{mL}$, while in the control group, the highest mean value of serum substance $\mathrm{P}$ level in the moderate stress scale was $52.3 \pm 18 \mathrm{pg} / \mathrm{mL}$.

Correlations between stress scale and serum substance $P$ level in acne vulgaris are illustrated in Table 5. This study found that there was a positive and significant correlation between stress scale and serum substance P level in acne vulgaris patients with moderate strength $(r=0.446$; $\mathrm{p}=0.014)$. Meanwhile stress scale and serum substance $P$ level in controls had a negative and no significant correlation with very low strength $(\mathrm{r}=-0.090 ; \mathrm{p}=$ 0.636), as shown in Table 6.

\section{Discussion}

This research was conducted with 30 acne vulgaris patients. The majority of acne vulgaris patients were 23-27 years old (36.7\%) and most of them were female (76.7\%). Rahmayani et al reported that the majority of acne vulgaris patients were 17-25 years old, whereas Sutrisno et al reported that the highest age range for acne vulgaris patients was $21-25$ years. ${ }^{711}$ Eyaboglu et al and

Table 5 Correlation Between Stress Scale and Serum Substance $P$ Level in Acne Vulgaris

\begin{tabular}{|l|c|l|c|}
\hline \multirow{2}{*}{} & \multicolumn{3}{|c|}{ Serum Substance P Level } \\
\cline { 2 - 4 } & $\mathbf{r}$ & $\mathbf{p}$ & Correlation \\
\hline Stress Scale & 0.446 & 0.014 & Positive \\
\hline
\end{tabular}

Table 6 Correlation Between Stress Scale and Serum Substance $P$ Level in Controls

\begin{tabular}{|l|c|l|c|}
\hline \multirow{2}{*}{} & \multicolumn{3}{|c|}{ Serum Substance $\mathbf{P}$ Level } \\
\cline { 2 - 4 } & $\mathbf{r}$ & $\mathbf{P}$ & Correlation \\
\hline Stress Scale & 0.090 & 0.636 & Negative \\
\hline
\end{tabular}


Rahmayani et al also reported in their study that females were more affected by acne vulgaris than males. ${ }^{11,12}$

Williams et al reported that acne vulgaris can affect people over the age of 24 , especially women. The cause of persistent acne vulgaris is not fully understood. The prevalence of acne vulgaris in adult females has increased in recent years. This is due to the high social pressure on adult females, especially the demands of work or careers in addition to the duties as a mother and wife. Stress is correlated with increased production of adrenal androgens, sebum and comedogenesis. ${ }^{13-15}$

This study found that the majority of acne vulgaris subjects had a low stress scale of $56.7 \%$, followed by a moderate stress scale of $40 \%$. Rokowska-Waluch et al conducted a study on 80 patients with acne vulgaris. The stress scale of these patients was examined using a social readjustment rating scale questionnaire. The majority of these patients had a moderate stress scale. ${ }^{16}$ Research by Ratnasari et al in Bali stated that the stress scale most frequently found was moderate, represented by 229 people $(91.6 \%)$ of the total 250 samples taken. ${ }^{17}$ Differences in the stress scale in this study were caused by differences in population and the type of questionnaire that we used.

This study discovered that major changes in sleeping habits, vacation, personal habits and eating habits were the principal causes of stress in acne vulgaris patients. The majority of these stressors may be due to the ongoing pandemic at the time of this research, which is causing these sorts of changes in this population of research subjects. There was strong evidence that the correlation between stress and acne vulgaris was centered on the HPA axis affecting sebaceous gland function. The HPA axis was thought to be one of the main pathways used by the central nervous system to control the immune system under stressful conditions. Activation of the HPA axis due to stress affected regulation of the main stress hormones, namely $\mathrm{CRH}, \mathrm{ACTH}$ and cortisol. Through these stressrelated hormones, accompanied by stress response mediators such as neuropeptides or neurotrophins, changes in the immune response occurred. , $^{9,18,19}$

In the acne vulgaris group, the highest mean value of serum substance $\mathrm{P}$ level was found in the high stress scale group, 168,2 pg/mL, while in the control group, the highest mean value of serum substance $P$ level was found in the moderate stress scale group, $52.3 \pm 18$. RokowskaWaluch et al in Poland stated that the highest mean value of serum substance $P$ level was found in the high stress scale group, $0.67 \pm 0.07 \mathrm{pg} / \mathrm{mL}$, followed by the low stress scale group, $0.59 \pm 0.12 \mathrm{pg} / \mathrm{mL}$, but this was not statistically significant. ${ }^{16}$ Table 4 shows the linear configuration in the acne vulgaris group, that is, the higher the stress scale, the higher the serum substance $\mathrm{P}$ level, which is not shown in control group. The stress scale was, however, highest in 2 individuals in the control group and the serum substance P level was lowest in the same individuals; this condition may be due to other factors that impact substance P level.

Substance $\mathrm{P}$ is a peptide composed of 11 amino acid residue bonds (undecapeptide) with the amino acid sequence Arg-Pro-Lys-Pro-Gln-Gln-Phe-Phe-Gly-LeuMet-NH2. Substance P is a family of peptides that are structurally similar to "tachykinins", including neurokinin A, neurokinin B, neuropeptide $K$, and neuropeptides $\gamma .^{20,21}$ Substance $\mathrm{P}$ is encoded by the tachykinin-1 (Tac1) gene (also known as preprotachykinin-A (PPTA)). Substance $\mathrm{P}$ is widely distributed in the peripheral nervous system and central nervous system, but has also been shown to be induced and expressed in other cell types such as monocytes, macrophages, lymphocytes, pancreatic acinar cells, Leydig cells and various tumors. ${ }^{21}$

There was a positive and significant correlation between stress scale and serum substance $\mathrm{P}$ level in the acne vulgaris group with medium strength. It indicated that the higher the stress scale, the higher the level of serum substance $\mathrm{P}$. Meanwhile, there was a negative and non-significant correlation between stress scale and serum substance P level in control groups with very low strength. It indicated that stress was affected by and correlated with acne vulgaris. Acne vulgaris is not likely to modify the association of stress with substance $\mathrm{P}$ in peripheral blood, which is a general but not specific biomarker of response to stressors. ${ }^{8}$ A possible explanation is that stress is less observed in control groups, such that there are not enough variations in both stress and serum substance $P$.

Research on stress scale and serum substance P level is still very limited. Rokowska-Waluch et al in Poland reported on the correlation between the social readjustment rating scale and serum substance $\mathrm{P}$ level. The experiment was carried out in the acne vulgaris and control groups. In this study, there was a statistically significant difference between stress scale and serum substance $P$ level in the control groups. However, there were no significant differences between stress scale and serum substance P levels among acne vulgaris patients. ${ }^{16}$ In the previous study, we found stress scale correlated positively in moderate strength with the severity of acne vulgaris. ${ }^{7}$ 
Peripheral nerves release substance $\mathrm{P}$ in response to stress. Substance $\mathrm{P}$ can stimulate the proliferation of sebaceous precursor cells and increase the size of sebocytes. This suggests that substance $\mathrm{P}$ can cause proliferation and differentiation of sebaceous glands and increase lipid synthesis in sebocytes. Stress can also inhibit wound healing by up to $40 \%$, so that it can affect the improvement of acne vulgaris lesions. ${ }^{3,19,22}$

A study in Korea by Lee et al conducted an examination of the possible involvement of neurogenic factors in the pathogenesis of acne vulgaris. In this study, immunohistochemical examinations and RT-PCR were carried out to compare the expression of interleukin-1 (IL-1), interleukin-6 (IL-6), tumor necrosis factor- $\alpha$ (TNF- $\alpha$ ) and peroxisome proliferator-activated receptors- $\gamma$ (PPAR- $\gamma$ ) on sebocyte culture stimulated by substance P. The results of this study showed an increase in immunoreactivity against IL-1, IL-6, TNF- $\alpha$ and PPAR- $\gamma$, and increased amplification of ribonucleic acid (RNA) against IL-1, IL-6, TNF- $\alpha$ and PPAR- $\gamma$ observed after addition of substance $\mathrm{P}$ compared with controls. This study demonstrated the possible role of substance $\mathrm{P}$ in the pathogenesis of acne vulgaris. $^{23}$

The limitation of this study is that female patients were predominant in our hospital-based sample. In populationbased studies, men are more likely to develop acne vulgaris but less willing to seek help. Research on substance $\mathrm{P}$ is still very limited, especially in relation to acne vulgaris. Further research is needed to assess the correlation between stress scale, serum substance $P$ level and severity of acne vulgaris.

Based on this study, stress was correlated with acne vulgaris. In managing acne vulgaris patients, stress assessment as well as education is necessary, particularly with those patients with acne vulgaris that we believe is triggered by stress, so that we can treat them better using a more holistic approach.

\section{Conclusion}

There was a correlation between stress scale and serum substance $\mathrm{P}$ level in acne vulgaris patients.

\section{Acknowledgments}

We would like to express gratitude to the Head of Department of Dermatology and Venereology of Faculty of Medicine Universitas Sumatera Utara and Universitas Sumatera Utara Hospital.

\section{Disclosure}

The authors report no conflicts of interest in this work.

\section{References}

1. Goh C, Cheng C, Agak G, et al. Acne vulgaris. In: Kang S, Amagai M, Bruckner AL, et al., editors. Fitzpatrick's Dermatology in General Medicine. 9th ed. New York: Mc Graw Hill Inc; 2019:1391-1418.

2. Marks JG, Miller JJ. Lookingbill and Marks' Principles of Dermatology. 5th ed. China: Elsevier; 2013.

3. Layton AM, Eady EA, Zouboulis CC. Acne. In: Griffiths CEM, Barker J, Bleiker T, Chalmers R, Creamer D, editors. Rook's Textbook of Dermatology. 9th ed. UK: John Wiley \& Sons; 2016:90.1-90.50.

4. James WD, Elston DM, Berger TG. Andrews' Diseases of the Skin Clinical Dermatology. 12th ed. Philadelphia: Elsevier; 2016.

5. Bhate K, Williams HC. Epidemiology of acne vulgaris. $\mathrm{Br}$ J Dermatol. 2013;168(3):474-485. doi:10.1111/bjd.12149.

6. Wasitaatmadja SM, Arimuko A, Norawati L, Bernadette I. Pedoman Tata Laksana Akne di Indonesia. In: Kelompok Studi Dermatologi Kosmetik Indonesia Perhimpunan Dokter Spesialis Kulit Dan Kelamin Indonesia. Jakarta: Centra Communication; 2nd ed; 2015.

7. Sutrisno AR, Jusuf NK, Putra IB. Correlation between stress scale and severity acne vulgaris. Bali Med J. 2020;9(1):376-379. doi:10.15562/bmj.v9i1.1749

8. Yosipovitch G, Tang M, Dawn AG, Chen M, Chan YH, Seng LF. Study of psychological stress, sebum production, and acne vulgaris in adolescents. Acta Derm Venerol. 2007;87:135-139. doi:10.2340/ 00015555-0231.

9. Wardhana M. Psikoneuroimunologi di bidang dermatologi. MDVI. 2011;38(4):175-180.

10. Ganceviciene R, Graziene V, Fimmel S, et al. Involvement of the corticotropin-releasing hormone system in the pathogenesis of acne vulgaris. Br J Dermatol. 2009;160(2):345-352. doi:10.1111/j.13652133.2008.08959.x.

11. Rahmayani T, Putra IB, Jusuf NK. Association of serum interleukin10 (IL-10) with the severity of acne vulgaris. Bali Med J. 2019;8 (3):573-576. doi:10.15562/bmj.v8i3.1514

12. Eyuboglu M, Kalay I, Eyuboglu D. Evaluation of Adolescents Diagnosed with Acne Vulgaris for Qualityof Life and Psychosocial Challenges. Indian J Dermatol. 2018; 63(2): 131-35.

13. Williams C, Layton AM. Persistent acne in women: implications for the patient and for therapy. Am J Clin Dermatol. 2006;7(5):281-290. doi:10.2165/00128071-200607050-00002

14. Jovic A, Marinovic B, Kostovic K, Ceovic R, Basta-Juzbasic A, Mokos ZB. The impact of psychological stress on acne. Acta Dermtovenereol Croat. 2017;25(2):133-141.

15. Bagatin E, Freitas THP, Rivitti-Machado MC, et al. Adult female acne: a guide to clinical practice. An Bras Dermatol. 2019;94 (1):62-75. doi:10.1590/abd1806-4841.20198203

16. Rokowska-Waluch A, Pawlaczyk M, Cybulski M, et al. Stressful events and serum concentration of substance $\mathrm{P}$ in acne patients. Ann Dermatol. 2016;28(4):464-469. doi:10.5021/ad.2016.28.4.464.

17. Ratnasari LPAP, Indira IGAAE. Profil tingkat stres psikologis terhadap derajat keparahan akne vulgaris pada siswa sekolah menengah atas di Denpasar. E-J Medika. 2017;6(1):1-6.

18. Arck PC, Slominski A, Theoharides TC, Peters EMJ, Paus R. Neuroimmunology of stress: skin takes center stage. $J$ Invest Dermatol. 2006;126(8):1697-1704. doi:10.1038/sj.jid.5700104.

19. Yadav S, Narang T, Kumaran MS. Psychodermatology: a comprehensive review. Indian J Dermatol Venereol Leprol. 2013;79(2):176-192. doi:10.4103/0378-6323.107632. 
20. Suvas S. Role of substance P neuropeptide in inflammation, wound healing and tissue homeostasis. J Immunol. 2017;199:1543-1552. doi:10.4049/jimmunol.1601751

21. Koh YH, Bhatia M. Substance P. Pancrepedia. 2011;1:6.

22. Zari S, Alrahmani D. The association between stress and acne among female medical students in Jeddah, Saudi Arabia. Clin Cosmet Investig Dermatol. 2017;10:503-506. doi:10.2147/CCID.S148499.
23. Lee WJ, Jung HD, Lee HJ, Kim BS, Lee SJ, Kim DW. Influence of substance $\mathrm{P}$ on culture sebocytes. Arch Dermatol Res. 2008;300:311-316. doi:10.1007/s00403-008-0854-1

\section{Publish your work in this journal}

The International Journal of General Medicine is an international, peer-reviewed open-access journal that focuses on general and internal medicine, pathogenesis, epidemiology, diagnosis, monitoring and treatment protocols. The journal is characterized by the rapid reporting of reviews, original research and clinical studies across all disease areas. The manuscript management system is completely online and includes a very quick and fair peer-review system, which is all easy to use. Visit http://www.dovepress.com/ testimonials.php to read real quotes from published authors. 